\title{
Comparison of the pressure gradients obtained by calculation with the pressure gradients obtained by catheterization in patients with aortic valve stenosis
}

\author{
T. Šušteršič ${ }^{1 *}$, S. Savić ${ }^{1}$, V. Šušteršič ${ }^{1}$ \\ ${ }^{1}$ Faculty of Engineering, Sestre Janjić 6, 34000 Kragujevac, Republic of Serbia \\ tijana.sustersic93@gmail.com \\ * Corresponding author
}

\begin{abstract}
This paper presents calculation of the pressure gradient at the point of aortic stenosis in patients with valvular aortic stenosis. The pressure gradients obtained by calculation were compared with the pressure gradients measured using catheterization in 12 patients with valvular aortic stenosis. It has been found that the maximum separation factor influences the maximum blood flow velocity $(p<0.05)$, which was used in calculation of the pressure gradient. There were no statistically significant differences in the pressures obtained by calculation and the pressures obtained by catheterization $(\mathrm{p}<0.05)$. These results are in compliance with the widespread use of Doppler echocardiography in practice as a substitute for invasive methods for determining the degree of aortic stenosis. The Doppler echocardiography method is based on calculation presented in this paper.
\end{abstract}

Keywords: aortic stenosis, pressure gradient, catheterization

\section{Introduction}

The aortic valve is the trefoil valve located between the left ventricle and the aorta. During the ejection of blood from the heart it opens allowing blood to exit the left ventricle into the aorta (heart contraction phase). Before the beginning of the heart filling phase, the aortic valve closes preventing blood from the aorta from entering the heart so that the left part of the heart is filled only from the atrium. In this way, the return of blood from the aorta into the left ventricle in the diastole phase is prevented (Sacks et al. 2007).

Aortic valve stenosis is the most common disease of the valve. It comprises $75 \%$ of all aortic diseases (AS) (Tornos 2001). It is basically a degenerative disease and its frequency increases with age. The most common form of aortic stenosis is caused by degenerative valvular calcification. The leaflets are thickened due to calcification and as a result of thickening of the atherosclerotic aortic valves, there is a reduction of the aortic valve opening (aortic separation) which leads to systolic load of left ventricle (LV). This narrowing (reduction of aortic separation) prevents the valve from opening fully, which obstructs blood flow from heart into aorta and onward to the rest of the body. Due to these changes, the valve does not fully close during the phase of the cardiac cycle when it should be closed, but allows blood to return in the opposite direction from its normal flow. This loads the heart muscle and weakens it. The smaller amount 
of aortic separation of the valve partially prevents blood from flowing from the left ventricle into the aorta in the contraction phase of the heart - systole. Consequently, this leads to thickening of the left ventricular wall, because the LV makes an effort to pump the same amount of blood, but now through a narrow opening (Figure 1). Diminished aortic separation is therefore used as an indicator of the severity of aortic stenosis (Chang 1977).

A large pressure gradient of the aortic valve causes left ventricular hypertrophy. In early stages of aortic stenosis, the left ventricular muscle compensates for the narrow opening of the aortic valve, but over time, the compensatory mechanism fail and early subjective symptoms appear in patients. As the disease progresses, fibrosis and calcification of the valve increase the thickness of the valve and reduce the orifice area during systole, which leads to the reduction of the flow rate through the heart (Tavčiovski 2008).
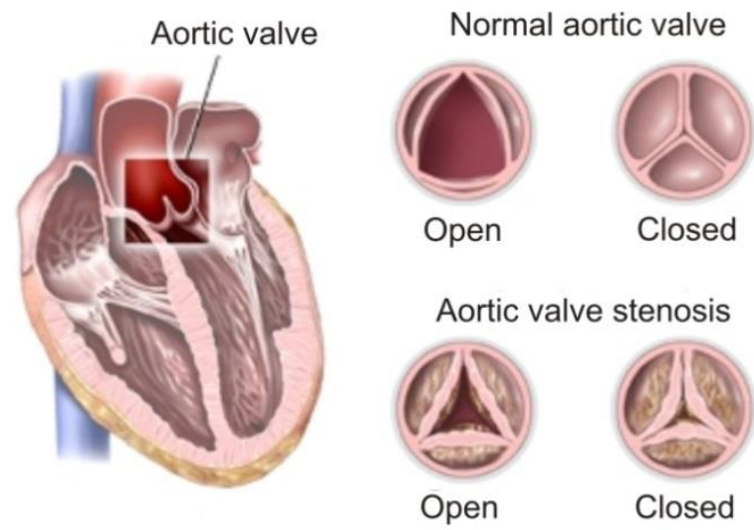

Fig. 1. Cross-sections of a normal aortic valve and a stenotic aortic valve

There is also a physiological constriction of the aortic valve, so the diameter is about $20 \mathrm{~mm}$. In patients with $\mathrm{AS}$, the aortic valve diameter is only 3-5 $\mathrm{mm}$. Blood pressure is high in the part above the narrowing of the valve, while it is low below the narrowing. As the upper part of the aorta supplies head and upper extremities with blood, the pressure in these parts of the body is normally higher than the pressure in lower extremities.

For the blood flow in the heart and the major blood vessels, inertial forces are more dominant than viscous forces. The Reynolds number at the maximum of systole is of the order of magnitude of $\operatorname{Re}=1000$ (Varghese et al. 2005). Blood flow in the aorta in the pulmonary part of the body is similar to the flow of input velocity profiles that have not been developed yet. For this reason it can be assumed that the central flow area is a non-viscous region surrounded by developed boundary layers towards the wall (Filipović 2012).

Cardiac catheterization is a diagnostic method in which a catheter (a thin flexible plastic tube) is inserted into the heart through the previously inserted cannula at the entrance of artery or vein in the groin or arm. Catheterization is used for injection of medication into the bloodstream, direct measurement of the pressure in the heart chambers, displaying the heart cavities and coronary arteries using contrasting color visible on X-ray, etc. Although this method is used for accurate measurements of the pressure gradient in AS patients, it is considered invasive. Therefore, the use of other non-invasive techniques such as transthoracic and transesophageal echocardiography is recommended.

The main aim of this study is to determine the pressure gradient at the point of aortic valve stenosis based on the aortic diameter, blood flow velocities, and the maximum aortic separation. 
The results obtained by calculation were compared with data on the pressure gradients measured by cardiac catheterization.

\section{The passage of blood in the aorta at the site of stenosis}

As the blood flow passes through the point of AS, it forms a jet which is contracted through a minimum cross-sectional area (effective orifice area, hereinafter referred to as EOA) (Figure 2, cross-section 2). The difference between the static pressure before the constriction $\left(\mathrm{P}_{\mathrm{LV}}-\right.$ left ventricular pressure) (Figure 2, cross-section 1) and the static pressure at the point of AS is referred to as the maximum transvalvular pressure gradient $\left(\mathrm{TPG}_{\max }\right)$, whereas the difference between the $\mathrm{P}_{\mathrm{LV}}$, and so-called recovered pressure (pressure after stenosis) ( $\mathrm{P}_{\mathrm{A}}$ - aotric pressure) is the net transvalvular pressure gradient $\left(\mathrm{TPG}_{\text {net }}\right.$, Figure 2 , cross- section 3$)$.
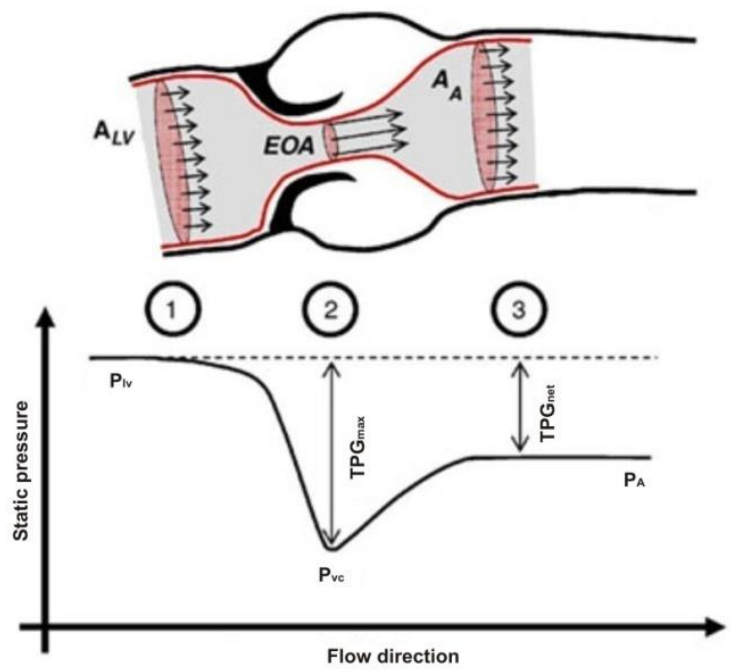

Fig. 2. Schematic representation of aortic stenosis with characteristic cross-sections

\section{Calculation of the pressure gradient at the point of aortic stenosis}

Due to complexity of blood as fluid, complex heart mechanisms and pumping of blood through the aorta, in order to perform calculations, it is necessary to introduce some assumptions and simplify the studied model.

Systole is defined as the period during which the blood is pumped from the heart and directed to the different parts of the body, so the transvalvular flow rate is $Q>0$. It is often referred to as a period of contraction that occurs during the opening of the aortic valve and the suppression of blood toward the organs (Garcia et al. 2006). Dynamic pressure is converted into static when the aorta narrows. This process is unstable and leads to turbulence, which means that part of the energy carried by blood as fluid is irretrievably lost. In contrast to this phenomenon, downstream from the narrowing of the aorta there is no turbulence, because stable conversion of the static into dynamic pressure does not lead to large energy losses (Ward-Smith 1980). For this reason and in order to simplify the model, we assume that blood is an ideal fluid upstream the point of AS. Furthermore, it is assumed that the aorta opens and closes instantaneously, and that the surface of the EOA remains constant during systole. Moreover, we assume that the velocity 
profile is flat through the observed area (just before the narrowing, at the point of AS and immediately after the narrowing).

The following derivation is given under the assumption that there is no substantial energy loss during convective acceleration (Miller 1996). During systole, blood accelerates between the cross-sections 1 and 2 (Figure 2). Neglecting the effects of gravity, the generalized Bernoulli equation applied to the streamline between the cross-sections 1 and 2 reads:

$$
T P G_{\max }=p_{L V}-p_{V C}=\frac{1}{2} \rho\left(V_{2}^{2}-V_{1}^{2}\right)+\rho \int_{1}^{2} \frac{\partial V}{\partial t} d l
$$

where $p$ is the static pressure, $V$ is the fluid velocity, and $\rho$ the density of the fluid. The coordinate $l$ is a curvilinear coordinate along the streamlines. Taking into account the law of mass conservation, the transvalvular flow rate $\mathrm{Q}$ can be written as:

$$
Q=A V_{1}=E O A V_{2}=A(l) V(l)
$$

where the $\mathrm{A}(l)$ is a cross-sectional area occupied by the through-flow at the location 1 . If we assume that $\mathrm{A}(\mathrm{l})$ does not depend on time, the equation (1) is transformed into:

$$
T P G_{\max }=\frac{1}{2} \rho Q^{2}\left(\frac{1}{E O A^{2}}-\frac{1}{A^{2}}\right)+\rho \frac{\partial Q}{\partial t} \int_{1}^{2} \frac{1}{A(l)} d l
$$

The integration of equation (2) over time eliminates the member-dependent flow $\mathrm{Q}$, which leads to a mean value of $\mathrm{TPG}_{\max }$ :

$$
\overline{T P G_{\max }}=\frac{1}{2} \rho \overline{Q^{2}}\left(\frac{1}{E O A^{2}}-\frac{1}{A^{2}}\right)
$$

where $\overline{T P G_{\text {max }}}$ refers to the time average value of the maximum transvalvular pressure gradient.

It can be noted that when EOA converges towards zero, the whole equation tends towards $+\infty$. On the contrary, when the stenosis becomes less and less severe, converging towards a non stenotic case, the location 2 tends towards the location 1 (Figure 2). Hence, if $E O A=A$ (no stenosis) $\overline{T P G_{\max }}$ equals 0.

It should be also emphasized that first part of the equation (2) includes convective acceleration which is the result of movement of the fluid out of the lower velocity field into the greater velocity field. The second part includes flow acceleration which occurs at the time of opening and closing of the valve, which is not relevant to the calculation of gradient pressure (Knežević 1990). Further transformation of the equation (2) includes average blood density of $\rho=1060 \frac{\mathrm{kg}}{\mathrm{m}^{3}}$. Since the equations (2) and (3) use the SI system of units and in clinical practice the $\mathrm{mm} \mathrm{Hg}$ unit is used for the pressure gradient, it is necessary to perform conversion of the density unit.

$$
\begin{gathered}
1 P a=0.0075 m m H g \\
P a=\frac{k g}{m^{3}} *\left(\frac{m^{3}}{s}\right)^{2} * \frac{1}{\left(m^{2}\right)^{2}} \\
1 \frac{k g}{m^{3}}=P a *\left(\frac{s}{m^{3}}\right)^{2} *\left(m^{2}\right)^{2}
\end{gathered}
$$




$$
\begin{gathered}
1 \frac{k g}{m^{3}}=\frac{P a * s^{2}}{m^{2}} \\
1 \frac{k g}{m^{3}}=0.0075 \frac{m m H g^{*} s^{2}}{m^{2}}
\end{gathered}
$$

Therefore $1060 \frac{\mathrm{kg}}{\mathrm{m}^{3}}=7.95 \frac{\mathrm{mmHg} * \mathrm{~s}^{2}}{\mathrm{~m}^{2}}$ and after division by 2 according to equation (3), the result is coefficient of 3.98, which can be rounded to 4 . The normal speed in the left ventricular outflow tract is from 0.7 to $1 \mathrm{~m} / \mathrm{s}$. This speed becomes significant only at the subvalvular obstruction.

Based on the stated parameters, the derived gradient is $4 V_{\max }{ }^{2}$, where $V_{\max }$ is the maximum registered jet velocity.

$$
T P G_{\max }=4 V_{\max }^{2}
$$

This is a simplified Bernoulli equation which is suitable for use in clinical practice.

\section{The data used in this study}

Table 1 shows echocardiographic parameters in 12 patients with valvular aortic stenosis, who underwent a complete clinical examination including the invasive tests. Based on the foregoing calculations and using the echocardiographic parameters, the pressure gradients given in Table 2 are calculated. The pressure gradients measured by catheterization are also given.

\begin{tabular}{c|ccc}
\hline Number & $\begin{array}{c}\text { Aortic Diameter } \\
(\mathbf{m m})\end{array}$ & $\begin{array}{c}\text { Maximal separation } \\
(\mathbf{m m})\end{array}$ & $\begin{array}{c}\text { Maximal flow } \\
\text { velocity (m/s) }\end{array}$ \\
\hline $\mathbf{1 .}$ & 20 & 10 & 3 \\
$\mathbf{2 .}$ & 25 & 10 & 4,637 \\
$\mathbf{3 .}$ & 19 & 11 & 4,27 \\
$\mathbf{4 .}$ & 19 & 7 & 4,69 \\
$\mathbf{5 .}$ & 19 & 10 & 3,8 \\
\hline $\mathbf{6 .}$ & 19 & 9 & 3,77 \\
$\mathbf{7 .}$ & 22 & 8 & 4,33 \\
$\mathbf{8 .}$ & 20 & 11 & 3,67 \\
$\mathbf{9 .}$ & 17 & 6 & 5,43 \\
$\mathbf{1 0 .}$ & 22 & 12 & 4 \\
$\mathbf{1 1 .}$ & 15 & 7 & 4,03 \\
$\mathbf{1 2 .}$ & 20 & 5 & 7,416 \\
\hline
\end{tabular}

Table 1. Significant parameters for assessment of aortic stenosis (Knežević 1990) 


\begin{tabular}{ccc}
\hline Number & $\begin{array}{c}\text { Calc. gradp } \\
(\mathbf{m m} \text { Hg) }\end{array}$ & $\begin{array}{c}\text { Cat. gradp } \\
(\mathbf{m m} \text { Hg) }\end{array}$ \\
\hline $\mathbf{1 .}$ & 36 & 55 \\
$\mathbf{2 .}$ & 86 & 90 \\
$\mathbf{3 .}$ & 73 & 75 \\
$\mathbf{4 .}$ & 88 & 90 \\
$\mathbf{5 .}$ & 58 & 60 \\
$\mathbf{6 .}$ & 57 & 60 \\
$\mathbf{7 .}$ & 75 & 90 \\
$\mathbf{8 .}$ & 54 & 60 \\
$\mathbf{9 .}$ & 118 & 130 \\
$\mathbf{1 0 .}$ & 64 & 66 \\
\hline $\mathbf{1 1}$ & 65 & 57 \\
$\mathbf{1 2 .}$ & 220 & 200 \\
\hline
\end{tabular}

Table 2. The pressure gradients obtained by calculation and cardiac catheterization

\section{Results and Discussion}

The data were processed in the software package SPSS 18.0.

Descriptive statistics was used to calculate the mean values of the pressure gradients at the point of aortic stenosis (the cross-sectional area EOA), both for pressures obtained by calculation and those measured by catheterization (Table 3 ).

\begin{tabular}{lccccc}
\hline & $\begin{array}{c}\text { No. of } \\
\text { patients }\end{array}$ & Minimum & Maximum & Mean value & $\begin{array}{c}\text { Standard } \\
\text { deviation }\end{array}$ \\
\hline calculation & 12 & 36.00 & 220 & 82.8333 & 47.88971 \\
catheterization & 12 & 55.00 & 200 & 86.0833 & 41.92083 \\
\hline
\end{tabular}

Table 3. Mean values of the gradient pressure at the intersection of EOA

It was found that there was no statistically significant difference in the pressures obtained by calculation and those obtained by direct measurements at the AS point (catheterization). The correlation coefficient is $\mathrm{r}=0.983$ which indicates a strong correlation between calculated gradient and pressure obtained by catheterization. Further analysis in a form of linear regression analysis $(\beta=0.86, \mathrm{SE}=0.051, \mathrm{t}=16.913)$ showed no statistically significant difference between the pressures obtained by calculation and those measured by catheterization $(\mathrm{p}<0.05)$. This result indicates that the data obtained by calculation can be used as indicators of the degree of aortic stenosis. Noninvasive calculation of the gradient pressure using data on aortic diameter, maximal separation and maximal flow velocity can be therefore useful for identifying patients with stenosis, especially when low transaortic flow is suspected.

These results are consistent with the practice, where, in fact, the previously stated method of calculation presents the basis for the non-invasive Doppler echocardiography, which is used to determine the pressure gradients in patients with AS. The use of the Doppler ultrasound in assessment of the degree of stenosis is based on the fact that the flow rate increases in the area of obstruction. However, for the measurement of the blood flow velocity, it is necessary to choose the position of the transducer that will give the flow rate curve of a regular shape. Moreover, the angle between the ultrasound beam and the aortic stream should be as small as possible, i.e., it is 
preferred that they are parallel (Knežević 1990). Using the maximum flow rate registered by the Doppler, the maximum transvalvular pressure gradient is calculated $\left(\mathrm{TPG}_{\max }\right)$.

Furthermore, the maximum aortic leaflet separation has shown a significant influence on the blood flow velocity at the point of aortic stenosis, and it is used to calculate the maximum transvalvular pressure gradient $\left(\mathrm{TPG}_{\max }\right)(\beta=-0.884$, standard error $=0.113, \mathrm{p}=0.003)$ (Figure 2). Since the reduction of the maximum aortic separation is a direct consequence of AS, it has a direct influence on the increase in the maximum blood flow velocity and an indirect impact on the on the maximum transvalvular pressure gradient $\left(\mathrm{TPG}_{\max }\right)$. With this figure we wanted to show that considering only blood velocity (and not maximal separation), based on final equation (4), it is possible to calculate maximum transvalvular pressure gradient $\left(\mathrm{TPG}_{\max }\right)$.

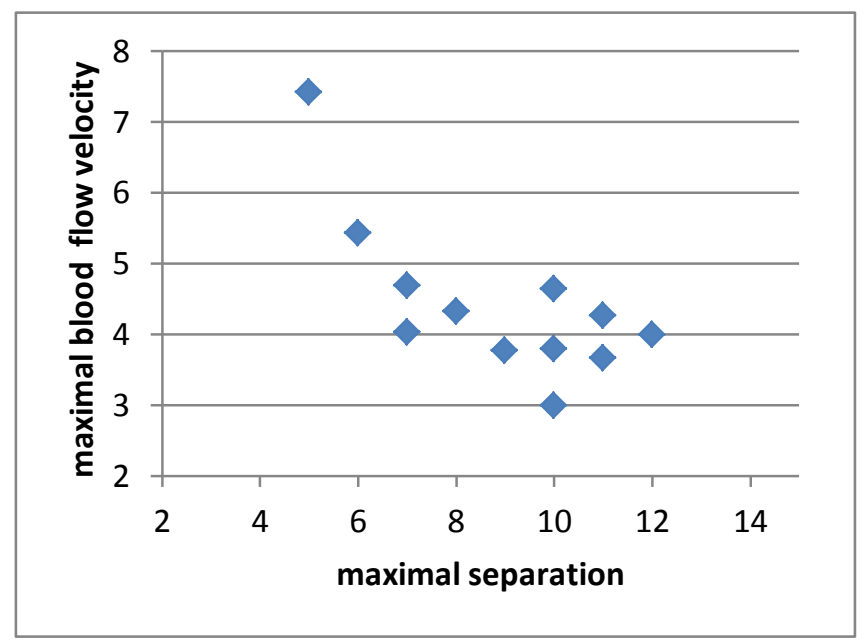

Fig. 3. Relation of the maximum separation and the maximum blood flow velocity at the point of aortic stenosis (measurement data)

Since the Doppler method for determination of the degree of aortic stenosis uses the velocity at the point of aortic stenosis, the maximum velocity is relevant for calculation presented in this paper (Figure 3). Furthermore, maximal separation which is related to severity of stenosis (reduction of maximal separation indicates more severe AS) has been shown to increase with decreasing flow rate. This result is consistent with previous findings by Garcia (2014).

In contrast, the catheterization gradient is the difference between the maximum pressure measured in the left ventricle of the heart and the pressure in the aorta after the constriction. In other words, when using catheterization, the so called recovered pressure at some distance after constriction is measured and it is given with the equation (Garcia 2006):

$$
\overline{T P G_{n e t}}=P_{L V}-P_{A}=\frac{1}{2} \rho \overline{Q^{2}}\left(\frac{1}{E O A^{2}}-\frac{1}{A^{2}}\right)
$$

This can cause differences in the pressures obtained by calculation and those obtained by catheterization because of the amount of "overestimation" of gradients obtained by calculation compared to catheter gradients. Although they were not statistically significant in this study, the differences in the pressures obtained using these two methods may become significant in patients with more advanced aortic stenosis, especially in those with severe forms of the disease (Baumgartner et al. 1999). Furthermore, in rigid aortic stenosis, gradient pressure is much less flow dependent than generally assumed. Indeed, it depends mainly on the inflow shape of the stenosis. The flow dependence of EOA observed in clinical studies is likely to be the result of a 
variation of the valve inflow shape and not an inherent flow dependence of the EOA derived by the continuity equation (Garcia 2004).

\title{
6. Conclusion
}

Precise determination of the degree of aortic stenosis is extremely important, and is done using different methods (Doppler echocardiography or catheterization). Cardiac catheterization is an accurate but invasive method, so the use of other methods is recommended whenever possible. Therefore, in this paper we wanted to determine whether there were differences between the pressures obtained by calculation and those measured by cardiac catheterization in 12 patients with valvular AS (Knežević 1990). It has been shown that the separation of aortic leaflets affects the maximum blood flow velocity at the point of AS (the maximum flow velocity was relevant for determining the gradient pressure at the point of AS in the presented calculation).

It has also been found that there are no statistically significant differences in the pressures obtained by calculation and by direct measurements at the point of AS, which confirms that Doppler echocardiography (which is based on the calculation presented in this paper) is a reliable method for the determination of the gradient pressure in patients with AS.

Based on the presented results we can conclude that Doppler echocardiography as a noninvasive method can be used to diagnose aortic stenosis with the same accuracy as the catheterization method. It is, therefore, possible to ascertain that these gradient results obtained numerically are directly applicable to the clinical situation and could be used to determine the presence of aortic stenosis. Therefore, catheterization as an invasive method should be avoided whenever possible, except in patients with a severe degree of AS.

Извод

\section{Упоређивање градијената притисака добијених рачунањем са градијентима притиска добијених катетеризацијом код пацијената који имају сужење аортног залиска}

\author{
Tijana Šušteršic ${ }^{1 *}$, Slobodan Savić ${ }^{1}$, Vanja Šušteršič ${ }^{1}$ \\ ${ }^{1}$ Факултет инжињерских наука, Сестре Јањић 6., 34000 Крагујевац, Република Србија \\ tijana.sustersic93@gmail.com \\ * Главни аитор
}

\section{Резиме}

Овај рад приказује резултате израчунавања градијента притиска на месту аортне стенозе код пацијената који имају сужење аортног залиска. Градијенти притиска добијени рачунањем су упоређени са градијентима притиска добијених катетеризацијом код 12 пацијената са дијагностикованим сужењем аортног залиска. Дошло се до закључка да максимални фактор сепарације утиче на максималну брзину протока крви $(\mathrm{p}<0.05)$, што је коришћено у израчунавању градијента притиска. Није било статистички значајне разлике у притисцима добијених рачунањем и притисцима донијених катетеризацијом ( $<0.05)$. Ови резултати су у складу са широком употребом Doppler ехокардиографије у пракси као замени за инвазивне методе за одређивање степена аортне стенозе. Метода Doppler ехокардиографије заснива се на израчунавању које је приказано о овом раду. 
Кључне речи: аортна стеноза, градијент притиска, катетеризација

\section{References}

Baumgartner H., Stefenelli T., et al. (1999). Overestimation of catheter gradients by Doppler ultrasound in patients with aortic stenosis: a predictable manifestation of pressure recovery. Journal of the American College of Cardiology, 33,1655-1661

Chang S, Clements S, Chang J. (1977) . Aortic stenosis: echocardiographic cusp separation and surgical description of aortic valve in 22 patients. American Journal of Cardiology, 39/4, 499-504

Filipović N. (2012). Osnovi bioinženjeringa. Fakultet inženjerskih nauka, Kragujevac

Garcia D., Kadem L., et al. (2006). Analytical modeling of the instantaneous maximal transvalvular pressure gradient in aortic stenosis. Journal of Biomechanics, 39, 3036-3044

Garcia D., Pibarot P. (2004). Estimation of Aortic Valve Effective Orifice Area by Doppler Echocardiography: Effects of Valve Inflow Shape and Flow Rate. Journal of the American Society of Echocardiography 17/7, 756-765

Knežević J. (1990). Ehokardiografske mogućnosti u dijagnostici i proceni stenoza aortnog ušća u dece. Magistarski rad. Medicinski fakultet, Univerzitet u Beogradu.

Miller D.S. (1996). Internal Flow Systems. BHR, Bedford.

Sacks M. S., Yoganathan A.P. (2007). Heart valve function: a biomechanical perspective. Phil. Trans. R. Soc., 362, 1369-1391

Tavčiovski D., Davičević Ž. (2008). Aortna stenoza: od postavljanja dijagnoze do optimalnog lečenja. BIBLID: 0354-2793, 136/ 2, 176-180

Tornos, P. (2001). New aspects in aortic valve disease. Revista Espanola de Cardiologia, 54, 17 21.

Varghese S.S, Frankel S. H., Fischer P. F. (2005). Direct numerical simulation of stenotic flows, Part 1: Steady flow. J. Fluid Mech., 1-25

Ward-Smith A.J. (1980). Internal Fluid Flow. The Fluid Dynamics of Flow in Pipes and Ducts., Clarendon Press, Oxford 